\title{
Design and Development Blended Learning Approach for Student Low Achievement in Mathematics
}

\author{
Parulian Silalahi* \\ Electrical Engineering and Informatics \\ State Polytechnic Manufacture of Bangka Belitung \\ Bangka Belitung, Indonesia \\ *fransiskussil@yahoo.com
}

\begin{abstract}
In general, mathematics is a difficult lesson for students. New students with low math skills will be a challenge in following the lectures. Therefore, an effort is needed to help overcome the problem. This research aims to design and develop a mathematics learning with blended learning approach. The research method used is research and development using the ADDIE model. The ADDIE model includes five steps: (1) analysis, (2) design, (3) development, (4) implementation and (5) evaluation. Respondents from this research are Electronics Engineering student's semester 1 academic year 2017/2018 with the number of 59 people. The findings show that through learning blended learning with developed media can help improve student learning outcomes.
\end{abstract}

Keywords-mathematical ability, blended learning, design and development, ADDIE model, learning outcomes

\section{INTRODUCTION}

The problem of the low level of mathematics ability of students who will continue their education in universities in the last few decades is still ongoing to this day. Sutherland and Prozzi reveal that engineering institutions in London face challenges to newly admitted students with low math qualifications [1]. Furthermore, Ashaari et al. states that the basic mathematics skills of students who will enter college have experienced a decrease in recent years, including new students who entered in Manufacturing Polytechnic State of Bangka Belitung [2]. New students with low math skills will be a challenge to a college. Rylands and Coday found that college students with low math skills often fail to follow the course in the first year [3], especially at universities with backgrounds in science and engineering [4]. It therefore improves how students learn to make them successful [5].

To overcome the problem of the math weakness some research has been done. Various methods and learning resources used by researchers [6]. Researchers know that the success of students in learning, not only determined by the quality of educators in teaching, but other factors need to be considered. In order to improve the quality of learning, learning strategies need innovation and use a new approach [7]. One of them is with the use of technology in learning. Some research results show that using technology can support learning mathematics and student science. In addition, technology can also provide motivation to students to learn math and science. With the help of technology various learning strategies can be done. One of them is with blended learning. Blended learning is one of the most commonly used learning models today [8].

In recent years, the results of new students' math tests have decreased the Bangka Belitung Manufacturing Polytechnic. This will be a problem for students who will attend lectures and challenges for lecturers who will teach. Such conditions if continuously left will have a negative impact on the quality of mathematics course learning, especially in the electronics engineering department of Manufacturing Polytechnic State of Bangka.

This is a serious problem that must be addressed by the institution, especially the lecturers who will teach. One of the above problems solving alternatives that will be attempted to study is to develop a model of mathematics learning using blended learning. In this research that will be produced is a model of learning development of engineering mathematics by using blended learning approach model.

From the main formulation of the problem, it can be detailed into several formulations of the problem as follows:

- How to design and development of learning mathematical engineering based learning outcome with blended learning approach?

- How are the results of learning mathematical engineering developed with blended learning approach?

\section{REVIEW OF THE RELATED LITERATURE}

\section{A. Blended Learning}

The terms blended learning, hybrid, or mixed learning modes are often interchangeable. Until now the notion of blended learning has still been growing. Simply blended learning can be interpreted as a learning method by using a combination of traditional or face-to-face with e-learning based learning. Kerres and De Witt suggest that blended learning refers to a mixture of didactical methods (expository presentations, discovery learning, cooperative learning, etc.) 
and delivery forms (personal communication, publishing, broadcasting, etc.) [9]. Blended learning refers to a program that combines face-to-face learning in the classroom with online learning [10]. Blended learning is: (1) combining instructional modalities [11]; (2) blended learning is combining instructional methods [12]; (3) blended learning is combining online and face-to-face [13].

Graham summarizes some blended learning definitions from several researchers and divides them into three parts [14]: (1) blended learning is combining instructional modalities; (2) blended learning is combining instructional; (3) blended learning is combining online and face-to-face instruction.

\section{B. Mathematics Learning Through Blended Learning}

In the context of mathematics learning, the main objective is to teach students that the planned learning objectives can be achieved. Therefore, the success criteria of the learning process is not only measured from the extent to which the students have mastered the subject matter, but measured from the extent to which students have done the process of learning mathematics. Therefore, what material should be studied and how to learn it is not solely determined by the lecturers' wishes, but it will pay attention to each student's differences. In accordance with the characteristics of student-oriented learning, then the process of learning mathematics can happen anywhere. Students can take advantage of various learning resources according to the needs and nature of the subject matter. Through learning blended learning students are given space to be able to learn independently through the media provided.

Currently blended learning has grown in popularity as it proves to be an effective approach to accommodate an increasingly diverse student population while adding value to the learning environment through the incorporation of resources available online [15]. The results of Kashefi et al. research suggests that learning with blended learning supports students' mathematical thinking and helps to overcome other obstacles in mathematics learning [16]. Learning by using blended learning can improve the learning process and students can manage learning independently [17].

\section{MethodOLOGY}

This study was research and development (R\&D). Respondents from this research are Electronics Engineering students semester 1 academic year 2017/2018 with the number of 59 people. This research use ADDIE model. The ADDIE model is a framework commonly used by a learning designer or training developer. This ADDIE model is a frequently used guide for designing learning and training. This model consists of five phases namely, Analyze, Design, Develop, Implement, and Evaluate. Stages of the process can be seen as in Figure 1 below:

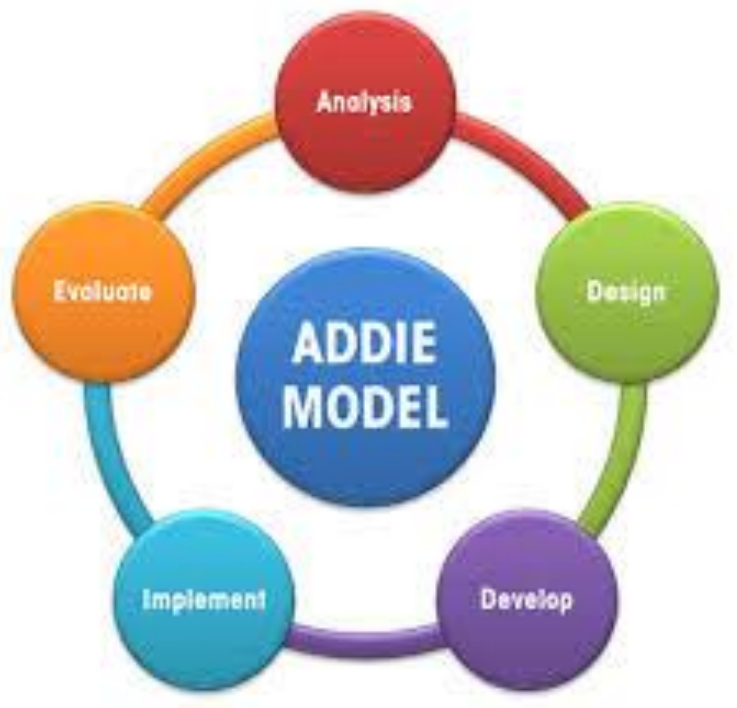

Fig. 1. Stages of the ADDIE model process

\section{RESULTS AND DISCUSSION}

\section{A. Analysis}

The design analysis phase focuses on assessing student characteristics, as well as identifying learning objectives. Since one of the goals underlying the design is to create more consistent subject matter among all sections, the learning objectives are developed from the existing curriculum of the college. Student difficulties were identified through an initial capability test analysis provided. Learning objectives are prepared by taking into account the order and structure of the subject matter to be provided. After the learning objectives are made, it is continued by identifying the most difficult learning objectives to be solved by the students. Analyzing student attitudes is important because the design phase begins because attitudes can help inform online and face-to-face activities that are made.

\section{B. Design}

Determination of implementation time using blended learning until now still no reference. Although many institutions that implement learning by using blended learning make the reduction of face time more drastic. Because students still have many difficulties in mathematics, in this case face-toface learning is still following the schedule that has been determined by the institution. Although the reduction of time in the classroom is one of the aims, but improving the success of the students is a top priority. The design phase focuses on instructional strategies that will enhance student interaction with the subject matter presented. The most important learning outcomes identified were critical thinking, teamwork and logical analysis. The educator decides that it creates. A collaborative learning environment that allows students to work in teams during face-to-face interaction will achieve this goal. The most difficult concept to identify. 


\section{Development}

After the analysis and the design is done, then the development of learning materials will be given online and face to face. For face-to-face learning modules developed for 12 sessions, with 2 hours each session. For online media developed using web 2.0. This application is quite easy to develop, and students are also easier to operate it. All presentation materials and syllabus to be studied during 1 semester are provided on online media. To explore the lesson material provided Learning videos and Links related to learning mathematics in online media developed. In addition, the tasks that will be done by students are also provided online and the work of students is also displayed.

\section{Implementation}

The design implementation phase begins at the beginning of the semester. Implementation of blended learning has been used by 59 students of electronics engineering Polytechnic Manufacturing Bangka Belitung starting in the first half of 2016. Each student is required to actively use the media that has been provided. After face-to-face learning is given, students do some of the questions given and will be displayed on the online media provided. After completion of 1 learning topic given, usually followed by giving quiz to the student. Students who score under 60 will be assigned to remedial of a failed topic.

\section{E. Evaluation}

Evaluation is done by looking at mathematics learning outcomes for one semester. In addition, questionnaires were given to students to get information about their perceptions of the use of the blended learning approach they did. For the learning outcomes are calculated based on the GPA obtained by the students with the assessment rules as the following table:

TABLE I. GRADE PoINT OF STUDENT ACHIEVEMENT

\begin{tabular}{|l|l|l|}
\hline \multicolumn{1}{|c|}{ Letters } & Number & \multicolumn{1}{c|}{ Category } \\
\hline $\mathrm{A}$ & 4 & Special \\
\hline $\mathrm{AB}$ & 3.5 & Very good \\
\hline $\mathrm{B}$ & 3 & Good \\
\hline $\mathrm{BC}$ & 2.5 & Pretty good \\
\hline $\mathrm{C}$ & 2 & Enough \\
\hline $\mathrm{D}$ & 1 & Less \\
\hline E & 0 & Very less \\
\hline
\end{tabular}

Learning outcomes of 59 students at the end of the semester are as follows:

TABLE II. MATHEMATICS ACHIEVEMENT TEST SEMESTER I 2017/2018

\begin{tabular}{|c|c|c|}
\hline Mark & Amount & Percentage \\
\hline $\mathrm{A}$ & 22 & $37.3 \%$ \\
\hline $\mathrm{AB}$ & 8 & $13.6 \%$ \\
\hline $\mathrm{B}$ & 11 & $18.6 \%$ \\
\hline $\mathrm{BC}$ & 10 & $16.9 \%$ \\
\hline $\mathrm{C}$ & 3 & $5.1 \%$ \\
\hline $\mathrm{D}$ & 5 & $8.5 \%$ \\
\hline
\end{tabular}

In addition to the results of mathematics tests, researchers also ask students to provide an assessment of learning blended learning provided. Focus group discussion was conducted by inviting as many as 8 students. One of the discussion questions with students does the media provided support their mathematical learning? The results of the discussion showed that in general can help the students in obtaining the subject matter. In addition, they can also more quickly browse other sources to deepen the subject matter provided.

\section{CONCLUSION}

Mathematics is a discipline with abstract analytical content, where students often experience difficulties especially students with low math skills. Therefore, it is necessary to develop a method or approach of learning for a subject that is difficult to learn. In this case selected approach by using blended learning. The stages used in developing mathematics learning by using blended learning follow the steps of the instructional design system. Design elements seem to work synergistically; the developed online media allows lecturers to move some of the content of their lectures online and reduce the classroom mock time. The preliminary results of this course design show that when technology and instructional strategies are aligned and properly integrated into the learning process, an integrated learning environment can facilitate students with outside classroom learning. Students have a more structured learning opportunity outside the classroom than they had before. Providing structured and routine tasks on online media provided to students seems to help improve their learning outcomes especially in students with low math skills. The media also allows students to work collaboratively with other students. The development of learning media with blended learning approach is still relatively new for higher education especially Polytechnic. Thus, it still requires further research and investigation in order to better understand and develop best practices in the field. Can benefit from research on how to apply the learning strategy as described here to improve student success in learning challenging content.

\section{ACKNOWLEDGMENT}

Special thank goes to all students participated in this research for their cooperation on providing information Their invaluable contributions are very much appreciated. We are also immensely grateful to Mr. Sugeng Ariyono that support this international joint conference.

\section{REFERENCES}

[1] R. Sutherland and S. Pozzi, "The changing mathematical background of undergraduate engineers: A review of the issues," Report prepared for The Engineering Council, 1995.

[2] N.S. Ashaari, H.M. Judi, H. Mohamed and M.T. Wook, "Student's Attitude towards Statistics Course," Procedia - Social and Behavioral Sciences, vol. 18, pp. 287-294, 2011.

[3] L. Rylands and C. Coady, Performance of students with weak mathematics in first-year mathematics and science. Int. J. Math. Educ. Sci. Technol. Vol. 40, no. 6, pp. 741-753, 2009.

[4] T. Wilson and H. MacGillivray, "Counting the basics: mathematical skills among tertiary entrants," International Journal of Mathematical Education in Science and Technology, vol. 38, no. 1, pp. 19-41, 2007. 
[5] S. Suan, joefel, "Proceeding of the Global Summit on Education GSE 2014 (E- ISBN 978-967-11768-5-6) 4-5 March 2014, Kuala Lumpur, MALAYSIA. Organized by WorldConferences.net, 2014.s

[6] Y.E. Faridhan, B. Loch and L. Walker, "Improving retention in firstyear mathematics using learning analytics. In H. Carter, M. Gosper and J. Hedberg (Eds.), Electric Dreams," Proceedings ascilite 2013 Sydney, pp.278-282, 2013

[7] N. Hoic-Bozic, V. Vornar and I. Boticki, "A blended learning approach to course design and implementation," IEEE Transactions on Education, vol. 52, no. 1 , pp. $19-30,2009$.

[8] P. Moskal, C. Dziuban and J. Hartman, Blended learning: A dangerous idea?, 2013.

[9] M. Kerres and C. De Witt, "A didactic framework for the design of blended learning arrangement," Journal of Education Media, vol. 28, no. 2-3, pp. 101- 113, 2003

[10] C. Dziuban, J. Hartman, and P. Moskal, Blended learning. Educause Center for Applied Research, Research Bulletin, vol. 7. , 2004.

[11] Bersin and Associates, Blended learning: What works? An industry study of the strategy, implementation, and impact of blended learning. Oakland, CA: Bersin \& Associates, 2003.
[12] M. Driscoll, Blended Learning: Let's get beyond the hype, 2002. [Online]. Retrieved from http://www.elearningmag.com/elearning/article/articleDetail.jsp?id=117 55. $\mathrm{s}$

[13] J.E. Rooney, "Blending learning opportunities to enhance educational programming and meetings," Association Management, vol. 55, no. 5, pp. 26-32, 2003.

[14] C.R. Graham, S. Allen, and D. Ure, Blended learning environments: A review of the research literature, Unpublished manuscript, Brigham Young University at Provo, UT, 2003.

[15] A. Alammary, A. Carbone, and J. Sheard, "Blended learning in higher education: Three different design Approaches," Australasian Journal of Educational Technology, vol. 30, no. (4), 2014.

[16] H. Kashefi, I. Zaleha and M.Y. Yudariah, Supporting student mathematical thinking in the learning oftwo-variable functions through blended learning. Procedia - Social and Behavioral Sciences, vol. 46, pp $3689-3695,2012$.

[17] P. Fernadez, M.C. Rodríguez-Ponceb, M. Vega-Cruzc, M.L. Oliveras, Didactic innovative proposal for mathematic learning at the university by the blended model, 2014. 